\title{
Toleransi Antar Umat Beragama Perspektif KH. Ali Mustafa Yaqub
}

\author{
Dewi Anggraeni \\ Universitas Negeri Jakarta \\ dewianggraeni@unj.ac.id \\ Siti Suhartinah \\ Universitas Negeri Jakarta \\ Tinahhamid40@gmail.com
}

\begin{abstract}
This paper is to analyze the thinking of KH Ali Mustafa Yaqub on tolerance interreligious. Tolerance is urgent for giving solution for the problems religious in Indonesia today. The understanding of tolerance can create harmony inter-religious. This paper is a literature review of Ali Mustafa Yaqub books. The results of this study indicate that conflict inter-religious often occur and very easy to divide the nation one. Therefore need a meaningful interpretation related to good tolerance among the faithful will bring to the harmony of religious life.
\end{abstract}

Keywords: Tolerance, Inter-religious, KH Ali Mustafa Yaqub

\begin{abstract}
Abstrak
Penelitian bertujuan untuk mengetahui pemikiran KH. Ali Mustafa Yaqub mengenai toleransi antar umat beragama untuk dijadikan satu solusi dalam menjawab permasalahan umat beragama di Indonesia saat ini, yakni permasalahan krisisnya sikap toleransi. Dengan pemahaman yang mendalam mengenai toleransi diharapkan dapat menciptakan kerukunan yang stabil antar umat beragama. Metode dalam penulisan artikel ini adalah kajian literatur atas buku-buku karya Ali Mustofa Yakub. Hasil penelitian menunjukan bahwa konflik antar umat beragama sering terjadi dan berpotensi memecah belah persatuan bangsa; karenanya diperlukan pemaknaan yang komprehensif terkait toleransi yang baik antar umat beragama.
\end{abstract}

Keywords: Toleransi,Umat Beragama, KH. Ali Mustofa Yaqub

\section{A. Pendahuluan}

Bangsa Indonesia dikenal sebagai bangsa yang majemuk, ditandai dengan banyaknya etnis, suku, agama, bahasa, budaya, dan adat-istiadat. Untuk persoalan agama, negara Indonesia secara konstitusional mewajibkan warganya untuk memeluk satu dari agama-agama yang diakui eksistensinya sebagaimana tercantum di dalam pasal 29 ayat (1) dan (2) UUD 1945. Negara memberi kebebasan kepada penduduk untuk memilih salah satu agama yang telah ada di Indonesia yaitu agama Islam, Kristen Protestan, Kristen Katolik, Hindu, Budha dan Konghuchu. Kenyataan ini dengan sendirinya memaksa negara untuk terlibat dalam menata kehidupan beragama. 
Ketentuan dalam pasal 29 UUD 1945 sangat penting artinya bagi agama-agama dan para pemeluknya karena telah memberi jaminan dan sarana keterlibatan umat di dalam mengisi dan memperkaya kehidupan berbangsa. Tiap pemeluk agama mendapatkan kesempatan untuk menjalankan agama dan menciptakan kehidupan beragama sesuai dengan ajaran agama masing-masing. Pengembangan agama dan kehidupan beragama tidak boleh menjurus ke arah tumbuhnya pemikiran dan pemahaman agama yang sempit karena hal ini akan menimbulkan konflik antar agama. Sebagaimana yang diungkapkan oleh Abdul Kadir, "Mengenai potensi integrasi akan terjadi apabila terdapat suasana keharmonisan hubungan dalam dinamika pergaulan terutama intern umat beragama dan antar umat beragama. Sebaliknya, potensi disintegrasi akan menjadi kenyataan apabila terdapat suasana saling curiga dan persaingan dalam dinamika baik intern umat beragama maupun antar umat beragama" " .

Kemajemukan bangsa Indonesia harus dipandang sebagai salah satu alat untuk memperkokoh persatuan dan kesatuan bangsa dengan selalu mengembangkan sikap toleransi, saling menghargai satu dengan lainnya. Atas dasar pemahaman tersebut, perbedaan-perbedaan yang ada dalam kehidupan masyarakat Indonesia sebenarnya untuk memenuhi kepentingan bersama agar dapat hidup rukun. Dalam kehidupan masyarakat yang serba majemuk, berbagai perbedaan yang ada seperti dalam suku, agama, ras atau antar golongan, merupakan realita yang harus didayagunakan untuk memajukan negara dan bangsa Indonesia, menuju cita-cita yang diinginkannya yang berdasarkan Pancasila dan UUD 1945 dalam Negara Kesatuan Republik Indonesia.

Kerukunan hidup umat beragama merupakan suatu sarana yang penting dalam menjamin integrasi nasional, sekaligus merupakan kebutuhan dalam rangka menciptakan stabilitas yang diperlukan bagi proses pencapaian masyarakat Indonesia yang bersatu dan damai. Kerjasama yang rukun dapat terjadi apabila diantara para pemeluk agama merasa saling membutuhkan, saling menghargai perbedaan, saling tolong menolong, saling membantu dan mampu menyatukan pendapat atau istilah lainnya memiliki sikap toleransi.

Toleransi dalam pergaulan antar umat beragama berpangkal dari penghayatan ajaran agama masing-masing. Demi memelihara kerukunan beragama sikap toleransi harus dijaga dan dipahami untuk menghindari konflik. Biasanya konflik antar umat beragama disebabkan oleh sikap merasa paling benar dengan cara mengeliminasi kebenaran orang

1. Abdul Kadir, 1992 :344, dalamlib.ugm.ac.id/jurnal/download.php?dataId=6666, diakses tanggal 27 November 2016 
lain. Ironisnya, hal tersebut menjangkit Indonesia yaitu krisisnya sikap toleransi antar umat bergama.

Menurut hipotesis penulis timbul akibat tidak adanya rasa menghargai, sikap merasa paling benar dan minimnya sikap toleransi yang ada pada diri umat beragama di Indonesia saat ini. Karenanya, diperlukan pemahaman kembali mengenai makna toleransi dalam menjalin hubungan antar umat beragama. Salah satu tokoh yang membahas terkait toleransi beragama KH.Ali Mustafa Yaqub. Dari latar belakang di atas penulis ingin mengesplor pemikiran K.H. Ali Mustofa Yaqub terkait pemikirannya mengenai toleransi dalam beragama, khususnya di Indonesia.

\section{B. Metodologi Penelitian}

Jenis penelitian yang dilakukan oleh penyusun adalah penelitian yang bersifat kepustakaan (library research) yaitu penelitian yang sumber datanya diperoleh melalui penelitian buku-buku yang berkaitan dengan masalah yang dibahas penelitian ini, baik melalui sumber data primer maupun sumber data sekunder. Adapun yang menjadi sumber data primernya disini adalah buku-buku yang membahas toleransi antar umat bergama dan juga yang terkait dengan kerukunan antar umat beragama, sedangkan yang menjadi sumber sekunder dalam penelitian ini adalah segala literatur ataupun hal-hal yang terkait dengan bahasan penelitian, seperti artikel, skripsi, tesis, maupun informasi- informasi yang di dapatkan dari dunia maya. Penelitian ini bersifat deskriptif analitik, dimana menghasilkan sebuah gambaran dengan menguraikan fakta-fakta yang bersifat kondisional dari suatu peristiwa. Hal ini dimaksudkan untuk mengetahui permasalahan yang diteliti secara gamblang dan terfokus. Penulis berupaya memaparkan dengan jelas pemikiran KH. Ali Mustafa Yaqub mengenai toleransi antar umat beragama.

Subjek penelitian ini adalah KH. Ali Mustafa Yaqub, sedangkan Objek penelitian adalah Pemikiran KH. Ali Mustafa Yaqub mengenai toleransi antar umat beragama.

Teknik yang digunakan penulis dalam melakukan penelitian ini adalah documenter, yakni dengan cara mengambil data-data dari referensi terkait dengan judul yang penulis angkat.

\section{Hasil dan Pembahasan}

\section{Biografi K.H.Ali Mustafa Yaqub}

Ali Mustafa Yaqub, lahir di Batang Jawa Tengah pada tahun 1952. Beliau hidup dalam lingkungan keluarga yang ta'at beragama, beliau juga termasuk dalam keluarga 
yang berada dan serba berkecukupan, Ali Mustafa Yaqub kecil tidak pernah merasa kekurangan dalam hal kebutuhan sehari-hari, setiap yang ia butuhkan selalu terpenuhi, namun beliau tidak pernah membanggakan kekayaan keluarganya, Ali dan kakakkakaknya dididik oleh kedua orang tua mereka untuk belajar hidup sederhana dan tidak berpoya-poya dan hidup mandiri serta taat kepada ajaran agama. ${ }^{2}$

Ayahnya beliau bernama (Mustafa Yaqub) seorang muballigh terkemuka pada zamannya dan imam di masjid-masjid yang ada di Jawa Tengah, misinya "Menegakkan Amal ma'ruf dan memberantas Nahi Mungkar". Sejak matahari terbit sampai terbenam ayahnya melakukan rutinitas belajar dan mengajar. Mayoritas penduduk dilingkungan rumahnya kebanyakan orang yang belum mengerti agama, baik dari kalangan petinggi pemerintahan, para guru-guru sekolah, masyarakat menengah sampai masyarakat awam (buta agama). Akhirnya ayah dan kakeknya mendirikan sebuah pondok pesantren yang para santrinya adalah penduduk disekitar. Ayah beliau mengajar tanpa pamrih dan hanya mengharap ridho Allah SWT, ayah beliau berjiwa besar dan bersahaja namun tegas dalam membela agama Allah SWT. Ibu beliau bernama Hj. Zulaikha, beliau seorang ustadzah dan Ibu rumah tangga, Ibu beliau ikut membantu perjuangan ayahnya, ibunya meninggal pada tahun1996. Beliau memiliki tujuh saudara, dari tujuh bersaudara tersebut dua diantaranya meninggal dunia, dan yang masih hidup lima bersaudara, salah satu dari kakanya yang bernama K.H. Ahmad Dahlan Nuri Yaqub mengikuti jejak ayahnya sama seperti beliau, dan sekarang kakanya sebagai Pegasuh Pondok Pesantren Darussalam di patang Jawa Tengah. Kakek dari ayah beliau bernama Joyo Truno, pekerjaannya seorang petani. Nama nenek dari ayah (beliau lupa). Pekerjaan nenek beliau ibu rumah tangga. Beliau menikah pada tahun 1986, nama istri beliau Ibu Hj. Ulfah Uswatun Hasnah, dari pernikahannya dengan $\mathrm{Hj}$. Ulfah, Beliau dikaruniai seorang anak perempuan yang bernama Ziaul haramain yang lahir pada tahun 1991, dan sekarang sedang menduduki pendidikan kelas tiga aliyah di Pondok Pesantren Sunan Pendanaran Yogyakarta. ${ }^{3}$

Ketika ia masih kecil kehidupan beliau sama seperti anak-anak pada umumnya. yang lainnya tumbuh besar bersama keluarganya, Tapi kebanyakkan masa kecil beliau dihabiskan untuk belajar agama dengan kakek dan ayahnya dari segi keuangan beliau tergolong keluarga yang berkecukupan. tepat ketika umurnya 7 (tujuh ) tahun beliau masuk Sekolah Rakyat (SR) pada tahun 1961 sampai dengan tahun 1966. Di sekolah teman-

\footnotetext{
2. Riki Efendi, Tentang Pemikiran dan Aktivitas Dakwah KH Ali Mustafa Yaqub, (Skripsi: UIN Syarif Hidayatullah, 2009)

${ }^{3}$. Riki Efendi, Tentang Pemikiran dan Aktivitas Dakwah KH Ali Mustafa Yaqub, (Skripsi: UIN Syarif Hidayatullah, 2009)
} 
teman beliau banyak meyukai beliau karena beliau anak yang mudah bergaul dan sangat cerdas, selain itu juga di kelas beliau tergolong siswa yang berprestasi dari kelas satu sampai dengan kelas enam.

Setelah tamat sekolah rakyat (SR) beliau melanjutkan pendidikan ke Madrasah Tsanawiyah (MTS) di daerahnya, setelah tamat Tsanawiyah beliau langsung melanjutkan pendidikan Aliyah di Pondok Pesantren Tebuireng Sebelak Jombang pada tahun 1966 sampai dengan tahun 1969. Setelah beliau kelas tiga (Aliyah) di Tebuireng1969-1971 setelah beliau meyelesaikan pendidikanya ditingkat menegah beliau berkeinginan melanjutkan ketingkat lebih tinggi lagi. Beliau mempunyai cita-cita ingin melanjutkan pendidikan kedokteran kata beliau "saya tidak pernah bercita-cita menjadi kiayi seperti sekarang ini, ya mungkin sudah takdir Allah SWT dan saya bersyukur atas takdirnya" .

Pada tahun 1972 beliau diperintahkan ayahanda agar melanjutkan pendidikannya di Universitas Hasyim Asy'ari yang lokasinya hanya beberapa ratus meter saja dari pondok pesantren Tebuireng. Di Universitas tersebut beliau masuk di Fakultas Syari'ah. Setelah pulang kuliah beliau langsung pulang ke Asrama untuk mendalami kitab-kitab kuning di bawah asuhan para kiayi sepuh (senior), antara lain al-marhum KH. Idris Kamali, al-marhum KH. Adlan Ali, al-marhum KH. Sobari, al-marhum KH. Al-Musnid Dan al-marhum KH. Samsuri Badawi di Pondok Pesantren Tebuireng Jombang Jawa Tegah sampai tahun 1975.

Pada tahun 1976 beliau melanjutkan pendidikan di Timur Tengah Saudi Arabiah di Fakultas Syari'ah Universitas Islam Imam Muhamad Bin Saud sampai selesai dengan ijazah Licance (Lc) pada Tahun 1980. kemudian masih di kota yang sama ia melanjutkan pendidikan pada Fakultas Dirosah Islamiyah di Universaitas King Saud, Departemen Study Islam Jurusan Tafsir dan Hadis, sampai selesai dan memperoleh ijazah Master pada Tahun 1985.

Pada tahun 1985 beliau pulang ke tanah air, namun terbenak dalam hati kecilnya, beliau ingin sekali pergi ke papua/Irian Jaya untuk mengabdikan dan mengamalkan ilmunya disana, akan tetapi beliau dipinta oleh pemerintah untuk mengbdikan dirinya dikota Jakarta, akhirnya beliau mengajar di Institut Ilmu al-Qur'an (IIQ) Jakarta. Kini disamping sebagai dosen tetap IIQ Jakarta, beliau juga mengajar di perguruan Tinggi Ilmu al-Qur'an (PTIQ), dan selain propesinya sebagai pengajar (Dosen) beliau mengisi Pengajian dan sebagai Imam Besar di Masjid Istiqlal Jakarta, dan di IAIN Syarif Hidayatullah Jakarta, yang sekarang berubah menjadi UIN Syarif Hidayatullah Jakarta. Ia juga pernah mengajar di Institut Agama Islam Shalahuddin Al-Ayyubi (INISA) Tambun 
Bekasi, Pendidikan Kader Ulama (PKU) MUI, dan Sekolah Tinggi Ilmu Dakwah (STDIA) Al-Hamidiyah Jakarta. Pada tahun 1989 beliau bersama keluarga mendirikan Pondok Pesantren Darussalam di batang Jawa Tengah Desa kelahirannya dan sekarang Pondok Pesantren tersebut diasuh oleh kakaknya yang bernama K.H. Ahmad Dahlan Nuri Yaqub. ${ }^{4}$ Beliau menghembuskan nafasnya pada bulan April tahun 2016.

Secara garis besar, pemikiran KH Ali Mustafa Yaqub dimulai dari beliau bersama teman- teman santri Darus- Sunnah mengaji dan mengkaji kitab- kitab Hadis yang enam (al-Kutub al-Sittah) yaitu: Shahih al-Bukhari, Shahih Muslim, Sunan Abu Dawud, Sunan al-Tarmidzi, Sunan al-Nasa'I dan Sunan Ibn Majah, mereka mendapatkan ketenganketerangan tentang "keakraban" hubungan antar umat- Islam dengan orang- orang nonMuslim (antar umat beragama). Menurut KH. Ali Mustafa Yaqub hal tersebut sangat menarik untuk dikaji, mengingat selama ini ada beberapa golongan umat yang mencapur adukan rasa toleransinya dengan akidah yang dimiliki. Pada saaat beliau berdiskusi, beliau mendapat telepon dari perwakilan Departemen Agama untuk menyampaikan uraian terkait Nuzul al-Qur'an. Tema yang akan beliau bawakan terkait permasalahan Indonesia saat itu , yaitu Meningkatkan Kerukunaan dan Persatuan bangsa. Beliau mengumpulkan Kitab-kitab Hadis dan Sirah Nabi Saw. Beliau mencari materi yang dapat memberikan petunjuk untuk hal tersebut. Mulai dari mencari petunjuk dari Al-Quran mengenai Nabi Saw memberikan contoh terkait, mencari apakah masyarakat yang di pimpin Nabi Saw terdapat Pluralisme, sebagaimana seperti halnya Indonesia. ${ }^{5}$

Latar belakang lain yang menurut penulis berkesinambungan dengan pemikiran beliau mengenai Toleransi antar umat beragama, saat MUI mengeluarkan fatwa mengenai menghadiri dan menyaksikan acara perayaan Natal bersama, fatwa tersebut berisi pengharaman terhadap umat Islam menghadiri perayaan Natal bersama, yang acara tersebut mempunyai maksud menghidupkan keharmonisan dan kerukunan antara pemelukpemeluk agama yang berbeda di Indonesia, yang dikenal sebagai Toleransi beragama. ${ }^{6}$ Namun, fatwa ini menimbulkan reaksi yang luar biasa ada yang berupa penolakan dan dukungan. Dari sinilah KH.Ali Mustafa Yaqub diminta MUI untuk menjelaskan masalah ini dan mengajukannya kepada Sidang Pleno Komisi Fatwa, sebagai penghormatan beliau

\footnotetext{
${ }^{4}$.Riki Efendi, Tentang Pemikiran dan Aktivitas Dakwah KH Ali Mustafa Yaqub, (Skripsi: UIN Syarif Hidayatullah, 2009)

5 . Prof. KH.Ali Mustafa Yaqub, Kerukunan Umat Perspektif Al-Quran dan Hadis (Jakarta: Penerbit Pustaka Firdaus, 2008), hal 13

6. Prof. KH.Ali Mustafa Yaqub, Toleransi antar umat beragama (Jakarta: Penerbit Pustaka Firdaus, 2008), hal 8
} 
terhadap tugasnya, beliau menuangkan pemikirannya pada paper terkait toleransi antar umat beragama.

\section{Tinjauan Umum tentang Toleransi antar Umat Beragama}

\section{Definisi Toleransi}

Menurut Kamus Umum Bahasa Indonesia, Toleransi yang berasal dari kata "toleran" itu sendiri berarti bersifat atau bersikap menenggang (menghargai, membiarkan, membolehkan), pendirian (pendapat, pandangan, kepercayaan, kebiasaan, dan sebagainya) yang berbeda dan atau yang bertentangan dengan pendiriannya.Toleransi juga berarti batas ukur untuk penambahan atau pengurangan yang masih diperbolehkan. Secara bahasa atau etimologi toleransi berasal dari bahasa Arab tasamuh yang artinya ampun, maaf dan lapang dada.

Secara terminologi, menurut Umar Hasyim, toleransi yaitu pemberian kebebasan kepada sesama manusia atau kepada sesama warga masyarakat untuk menjalankan keyakinannya atau mengatur hidupnya dan menentukan nasibnya masing-masing, selama dalam menjalankan dan menentukan sikapnya itu tidak melanggar dan tidak bertentangan dengan syarat-syarat atas terciptanya ketertiban dan perdamaian dalam masyarakat. ${ }^{7}$ Namun menurut W. J. S. Poerwadarminto dalam "Kamus Umum Bahasa Indonesia" toleransi adalah sikap/sifat menenggang berupa menghargai serta memperbolehkan suatu pendirian, pendapat, pandangan, kepercayaan maupun yang lainnya yang berbeda dengan pendirian sendiri. ${ }^{8}$

Istilah Tolerance (toleransi) adalah istilah modern, baik dari segi nama maupun kandungannya. Istilah ini pertama kali lahir di Barat, di bawah situasi dan kondisi politis, sosial dan budayanya yang khas. Toleransi berasal dari bahasa Latin, yaitu tolerantia, yang artinya kelonggaran, kelembutan hati, keringanan dan kesabaran. Dari sini dapat dipahami bahwa toleransi merupakan sikap untuk memberikan hak sepenuhnya kepada orang lain agar menyampaikan pendapatnya, sekalipun pendapatnya salah dan berbeda. Secara etimologis, istilah tersebut juga dikenal dengan sangat baik di dataran Eropa, terutama pada revolusi Perancis. Hal itu sangat terkait dengan slogan kebebasan, persamaan dan persaudaraan yang menjadi inti revolusi di Perancis. Ketiga istilah tersebut mempunyai

7. Umar Hasyim, Toleransi dan Kemerdekaan Beragama dalam Islam Sebagai Dasar menuju Dialoq dan Kerukunan Antar Umat Beragama, (Surabaya: Bina Ilmu, 1979), hal 22.

${ }^{8}$. W. J. S. Poerwadarminto, Kamus Umum Bahasa Indonesia (Jakarta: Balai Pustaka, 1986), hal 184. 
kedekatan etimologis dengan istilah toleransi. Secara umum, istilah tersebut mengacu pada sikap terbuka, lapang dada, sukarela dan kelembutan. ${ }^{9}$

Dari beberapa definisi di atas penulis menyimpulkan bahwa toleransi adalah suatu sikap atau tingkah laku dari seseorang untuk membiarkan kebebasan kepada orang lain dan memberikan kebenaran atas perbedaan tersebut sebagai pengakuan hak-hak asasi manusia.

\section{Macam-macam Toleransi}

\section{a.Toleransi Terhadap Sesama Agama}

Adapun kaitannya dengan agama, toleransi beragama adalah toleransi yang mencakup masalah-masalah keyakinan pada diri manusia yang berhubungan dengan akidah atau yang berhubungan dengan ke-Tuhanan yang diyakininya. Seseorang harus diberikan kebebasan untuk menyakini dan memeluk agama (mempunyai akidah) masingmasing yang dipilih serta memberikan penghormatan atas pelaksanaan ajaran-ajaran yang dianut atau yang diyakininya.

Toleransi mengandung maksud supaya membolehkan terbentuknya sistem yang menjamin terjaminnya pribadi, harta benda dan unsur-unsur minoritas yang terdapat pada masyarakat dengan menghormati agama, moralitas dan lembaga-lembaga mereka serta menghargai pendapat orang lain serta perbedaan-perbedaan yang ada di lingkungannya tanpa harus berselisih dengan sesamanya karena hanya berbeda keyakinan atau agama. Toleransi beragama mempunyai arti sikap lapang dada seseorang untuk menghormati dan membiarkan pemeluk agama untuk melaksanakan ibadah mereka menurut ajaran dan ketentuan agama masing-masing yang diyakini tanpa ada yang mengganggu atau memaksakan baik dari orang lain maupun dari keluarganya sekalipun. ${ }^{10}$

Dalam agama telah menggariskan dua pola dasar hubungan yang harus dilaksanakan oleh pemeluknya, yaitu : hubungan secara vertikal dan hubungan secara horizontal. Yang pertama adalah hubungan antara pribadi dengan Khaliknya yang direalisasikan dalam bentuk ibadat sebagaimana yang telah digariskan oleh setiap agama. Hubungan dilaksanakan secara individual, tetapi lebih diutamakan secara kolektif atau berjamaah (shalat dalam Islam). Pada hubungan ini berlaku toleransi agama yang hanya terbatas dalam lingkungan atau intern suatu agama saja. Hubungan yang kedua adalah hubungan antara manusia dengan sesamanya. Pada hubungan ini tidak terbatas panda lingkungan suatu agama saja, tetapi juga berlaku kepada semua orang yang tidak seagama,

${ }^{9}$. Umar Hasyim, Toleransi dan Kemerdekaan Beragama dalam Islam Sebagai Dasar menuju Dialoq dan Kerukunan Antar Umat Beragama, (Surabaya: Bina Ilmu, 1979), hal 22-23.

10. Masykuri Abdullah, Pluralisme Agama dan Kerukunan dalam Keragaman (Jakarta: Penerbit Buku Kompas, 2001), hal 13. 
dalam bentuk kerjasama dalam masalah-masalah kemasyarakatan atau kemaslahatan umum. Dalam hal seperti inilah berlaku toleransi dalam pergaulan hidup antar umat beragama. $^{11}$

\section{b. Toleransi Terhadap Non Muslim}

Toleransi dalam pergaulan hidup antar umat beragama berpangkal dari penghayatan ajaran masing-masing. Menurut said Agil Al Munawar ada dua macam toleransi yaitu toleransi statis dan toleransi dinamis. Toleransi statis adalah toleransi dingin tidak melahirkan kerjasama hanya bersifat teoritis. Toleransi dinamis adalah toleransi aktif melahirkan kerja sama untuk tujuan bersama, sehingga kerukunan antar umat beragama bukan dalam bentuk teoritis, tetapi sebagai refleksi dari kebersamaan umat beragama sebagai satu bangsa. ${ }^{12}$

Dari penjelasan di atas dapat dipahami bahwa toleransi antar umat beragama berarti suatu sikap manusia sebagai umat yang beragama dan mempunyai keyakinan, untuk menghormati dan menghargai manusia yang beragama lain. Dalam masyarakat berdasarkan pancasila terutama sila pertama, bertakwa kepada tuhan menurut agama dan kepercayaan masing-masing adalah mutlak. Semua agama menghargai manusia maka dari itu semua umat beragama juga wajib untuk saling menghargai. Dengan demikian antar umat beragama yang berlainan akan terbina kerukunan hidup.

\section{Prinsip-prinsip Toleransi Beragama}

Dalam melaksanakan toleransi beragama kita harus mempunyai sikap atau prinsip untuk mencapai kebahagiaan dan ketenteraman. Adapun prinsip tersebut adalah:

\section{a. Kebebasan Beragama}

Hak asasi manusia yang paling esensial dalam hidup adalah hak kemerdekaan atau kebebasan baik kebebasan untuk berfikir maupun kebebasan untuk berkehendak dan kebebasan di dalam memilih kepercayaan atau agama. Kebebasan merupakan hak yang fundamental bagi manusia sehingga hal ini yang dapat membedakan manusia dengan makhluk yang lainnya. Kebebasan beragama sering kali disalah artikan dalam berbuat sehingga manusia ada yang mempunyai agama lebih dari satu.

Yang dimaksudkan kebebasan beragama di sini bebas memilih suatu kepercayaan atau agama yang menurut mereka paling benar dan membawa keselamatan tanpa ada yang memaksa atau menghalanginya, kemerdekaan telah menjadi salah satu pilar demokrasi dari

\footnotetext{
11. Masykuri Abdullah, Pluralisme Agama dan Kerukunan dalam Keragaman (Jakarta: Penerbit Buku Kompas, 2001), hal 13-14.

12. Masykuri Abdullah, Pluralisme Agama dan Kerukunan dalam Keragaman (Jakarta: Penerbit Buku Kompas, 2001), hal 15
} 
tiga pilar revolusi di dunia. Ketiga pilar tersebut adalah persamaan, persaudaraan dan kebebasan. ${ }^{13}$ Kebebasan beragama atau rohani penulis artikan sebagai suatu ungkapan yang menunjukkan hak setiap individu dalam memilih keyakinan suatu agama.

\section{b. Penghormatan dan Eksistensi Agama lain}

Etika yang harus dilaksanakan dari sikap toleransi setelah memberikan kebebasan beragama adalah menghormati eksistensi agama lain dengan pengertian menghormati keragaman dan perbedaan ajaran-ajaran yang terdapat pada setiap agama dan kepercayaan yang ada baik yang diakui negara maupun belum diakui oleh negara. Menghadapi realitas ini setiap pemeluk agama dituntut agar senantiasa mampu menghayati sekaligus memposisikan diri dalam konteks pluralitas dengan didasari semangat saling menghormati dan menghargai eksistensi agama lain. Dalam bentuk tidak mencela atau memaksakan maupun bertindak sewenang-wenangnya dengan pemeluk agama lain. ${ }^{14}$

\section{c. Agree in Disagreement}

"Agree in Disagreement" (setuju di dalam perbedaan) adalah prinsip yang selalu didengugkan oleh Mukti Ali. Perbedaan tidak harus ada permusuhan, karena perbedaan selalu ada di dunia ini, dan perbedaan tidak harus menimbulkan pertentangan. ${ }^{15}$ Mewujudkan kerukunan dan toleransi dalam pergaulan hidup antar umat beragama merupakan bagian usaha menciptakan kemaslahatan umum serta kelancaran hubungan antara manusia yang berlainan agama, sehingga setiap golongan umat beragama dapat melaksanakan bagian dari tuntutan agama masing-masing.

\section{Toleransi dalam Pandangan K.H. Ali Mustof Yaqub}

Secara garis besar, pandangannya akan toleransi dipaparkan dengan poin sebagai berikut:

\section{a. Toleransi adalah Kewajiban}

Islam sangat menganjurkan sikap toleransi, tolong menolong, hidup yang harmonis, dan dinamis diantara umat manusia tanpa memandang agama, bahasa, dan ras mereka ${ }^{16}$, seperti yang telah dicantumkan pada QS. al-Mumtahannah ayat 8-9, yaitu ${ }^{17}$ :

13. Syamsul Hadi, Tentang Kerukunan Umat Beragama, (Tesis: Universitas Muhammadiyah Surakarta, 2005)

${ }^{14}$.Syamsul Hadi, Tentang Kerukunan Umat Beragama, (Tesis: Universitas Muhammadiyah Surakarta, 2005)

15. Syamsul Hadi, Tentang Kerukunan Umat Beragama, (Tesis: Universitas Muhammadiyah Surakarta, 2005)

16. Prof. KH.Ali Mustafa Yaqub, Toleransi antar umat beragama (Jakarta: Penerbit Pustaka Firdaus, 2008), hal 11

17. Al-Qur'an dan Terjemahan (Semarang: Penerbit Asy-Syifa', 1998), hal 438 
"Allah tidak melarang kamu untuk berbuat baik dan berlaku adil terhadap orang-orang yang tiada memerangimu karena agama dan tidak (pula) mengusir kamu dari negerimu. Sesungguhnya Allah menyukai orang-orang yang berlaku adil. Sesunggujmya Allah hanya melarang kamu menjadikan sebagai kawanmu orang-orang yang memerangimu karena agama dan mengusir kamu dari negerimu, dan membantu (orang lain) untuk mengusirmu. Dan siapa menjadikan mereka sebagai kawan, maka mereka itulah orang-orang yang zalim."

Berdasarkan ayat tersebut, KH. Ali Mustafa Yaqub berpendapat bahwa berbuat baik kepada non- Muslim merupakan kewajiban, selama orang-orang non-Muslim itu tidak memerangi dan mengusir umat islam dari negeri mereka, serta tidak membantu orang lain untuk mengusir umat islam dari negeri mereka. Selain itu, ketika Islam memerintahkan umatnya bermuamalah dengan non-Muslim, maka perintah itu tidaklah terlepas dari peringatan terhadap tindak kezaliman. Adapun peringatan bagi orang yang bertindak zalim terhadap non- Muslim yang mengadakan perjanjian dengan umat islam adalah ancaman tidak masuk surga. ${ }^{18}$ Dalam hal ini Nabi Bersabda, "Siapa yang membunuh (non-Muslim) yang terikat perjanjian dengan umat islam, maka ia tidak akan mencium keharuman surga. Sesungguhnya keharuman surga bisa dicium dari jarak empat puluh tahun perjalanan (di dunia).” (HR. Ahmad, al-Bukhari, al-Tirmidzi, al-Nasa'I, Ibn Majah)

Dapat diambil kesimpulan bahwa sikap toleransi, harmonis dan kerjasama antara umat Islam dan non- Muslim (umat beragama) yang dimaksud itu hanyalah dalam masalah kedunian yang tidak berhubungan dengan permasalahan akidah dan ibadah.

\section{b. Toleransi dalam Masalah Agama}

Ketika kota Mekkah dibebaskan dari kaum musyrikin , Bilal seorang sahabat Nabi yang berkulit hitam naik ke atas Ka'bah untuk mengumandangkan adzan. Melihat kejadian ini banyak yang berkomentar. Dan dari peristiwa tersebut Allah kemudian menurunkan ayat 13 Surah al-Hujarat, yaitu ${ }^{19}$ :

"Hai manusia sesungguhnya Kami menciptakan kamu dari seorang laki-laki (Adam) dan seorang wanita (Hawa) dan menjadikan kamu berbangsa-bangsa dan bersuku-suku supaya kamu saling kenal-mengenal. Sesungguhnya orang yang paling mulia diantara kamu di sisi Allah adalah yang paling bertaqwa di antara kamu. Sesungguhnya Allah Maha Mengetahui lagi Maha Mengenal."

Menurut KH. Ali Mustafa Yaqub, dalam ayat ini sekurang-kurangnya ada dua teori. Teori pertama, teori persamaan hak bagi manusia (Nadhariyah al-Musawah). Persamaan ini berlaku untuk seluruh manusia tanpa melihat perbedaan masing-masing individu,

18. Prof. KH.Ali Mustafa Yaqub, Toleransi antar umat beragama (Jakarta: Penerbit Pustaka Firdaus, 2008), hal 13

${ }^{19}$. Prof. KH.Ali Mustafa Yaqub, Kerukunan Umat Perspektif Al-Quran dan Hadis (Jakarta: Penerbit Pustaka Firdaus, 2008), hal 28 
kelompok, etnis, warna kulit, kedudukan, keturunan, dan lain sebagainya. Teori kedua, teori pengakuan atas eksistensi bangsa-bangsa dan suku-suku bangsa. Eksistensi bangsabangsa dan suku-suku bangsa ini diakui dan dikehendaki oleh Allah. Keberadaannya bukan untuk berbangga- banggaan apalagi melecehkan pihak lain. Melainkan untuk saling mengenali satu sama lain, termasuk mengenali kekurangan dan kelebihan pihak lain. ${ }^{20}$ Sehingga dapat mendorong terciptanya kondisi dimana satu sama lain saling menghormati, saling tolong menolong dan terciptanya kerukunan.

Bukti kedekatan Nabi saw kepada orang Nasrani adalah hubungannya dengan Pendeta Waraqah bin Naufal (sepupu Khadijah) yang membuat Waraqah menunjukan sikap simpatik kepada Nabi Saw. ${ }^{21}$

Sedangkan hubungan baiknya dengan kaum Yahudi tampak pada tahun 7 M, saat Nabi Saw bersama Shofiyah, puteri Huyai bin Akhtab, seorang tokoh Yahudi Bani Quraidhah di Khaibar. Mertua Nabi tetap sebagai Yahudi sampai meninggal dunia. Hubungan keduanya membuat rumah tangga Nabi Saw tidak menutup pintu bagi orangorang Yahudi (keluarga Shofiyah, istri Nabi). ${ }^{22}$

Kisah lain mengenai hubungan Nabi dengan Yahudi juga diterangkan dalam Kitab Shahih Bukhari dan Shahih Muslim bahwa Aisyah istri Nabi Saw sering berdiskusi dengan wanita-wanita Yahudi di rumah Nabi Saw, bahkan terkadang Nabi Saw terlibat dalam diskusi tersebut. ${ }^{23}$ Tentu sangat terlihat dari kisah- kisah tersebut, betapa Nabi Saw sangat menunjukan sikap toleransinya kepada kaum Yahudi

Pada umumnya, komponen-komponen bangsa tampaknya di nilai dapat berpotensi untuk dijadikan pemicu munculnya konflik dan disintegrasi. Karenanya Nabi Saw melakukan pendekatan-pendekatan untuk merekatkan bangsa. Beliau melakukan Pendekatan Mu'akhah (persaudaraan) antara kaum Muhajir dengan kaum Anshar, pendekatan ini sangat efektif sampai Sa'ad bin al-Rabi' (Anshar) bersedia untuk membagi hart dan isterinya kepada Abd al-Rahman bin A'uf (Muhajir). Ada satu pendekatan lagi yang dilaakukan Nabi Saw, yaitu Munakahah (pernikahan) antar suku. ${ }^{24}$

\footnotetext{
20. Prof. KH.Ali Mustafa Yaqub, Kerukunan Umat Perspektif Al-Quran dan Hadis (Jakarta: Penerbit Pustaka Firdaus, 2008), hal 31

${ }^{21}$. Prof. KH.Ali Mustafa Yaqub, Kerukunan Umat Perspektif Al-Quran dan Hadis (Jakarta: Penerbit Pustaka Firdaus, 2008), hal 34

${ }^{22}$. Prof. KH.Ali Mustafa Yaqub, Kerukunan Umat Perspektif Al-Quran dan Hadis (Jakarta: Penerbit Pustaka Firdaus, 2008), hal 38

${ }^{23}$. Prof. KH.Ali Mustafa Yaqub, Kerukunan Umat Perspektif Al-Quran dan Hadis (Jakarta: Penerbit Pustaka Firdaus, 2008), hal 39

${ }^{24}$. Prof. KH.Ali Mustafa Yaqub, Kerukunan Umat Perspektif Al-Quran dan Hadis (Jakarta: Penerbit Pustaka Firdaus, 2008), hal 42-43
} 
Walaupun Nabi memiliki hubungan yang dekat dengan banyak pihak, namun harus ada garis pemisah (batasan) dalam bertoleransi, sesuai QS. al-Kafirun ayat 6, yakni, "Bagimu agamamu, dan bagiku agamaku." Menurut KH. Ali Mustafa Yaqub, sesuai dengan latar belakang turunnya ayat tersebut, pemisahan itu adalah dalam masalah akidah dan ibadah saja. ${ }^{25}$ Karena itu Surah al-Kafirun itu merupakan pemisah (batasan) secara tegas antara umat beragama dalam bertoleransi pada aspek aqidah dan ibadah. Jelasnya, orang-orang muslim tidak dibenarkan melakukan kompromi agama atau toleransi agama dengan orang-orang non-muslim. Adapun toleransi di luar masalah agama, tepatnya di luar masalah aqidah dan ibadah, maka hal itu boleh- boleh saja selama orang-orang non Muslim itu tidak memusuhi orang-orang muslim. Maka kerja sama antara orang-orang muslim dengan orang-orang non- Muslim dalam masalah kedunian tetap dibolehkan. ${ }^{26}$

\section{c. Hal-Hal yang Diharamkan dalam Bertoleransi}

KH. Ali MustafaYaqub memaparkan hal-hal yang diharamkan dalam bertoleransi yang mencampuradukkan agama dan akidah, yang terdapat pada dalil dari Al-Quran, Sunnah, kaidah fikih, dan rasional, diantaranya sebagai berikut:

\section{1) Tolong menolong dalam Dosa}

Mengenai hal ini, KH. Ali Mustafa Yaqub merujuk pada Qs. Al-Maidah ayat 2 , yang artinya :

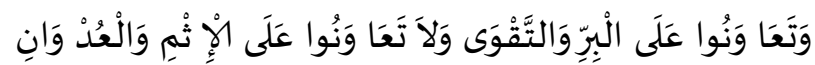

Tolong-menolonglah kamu dalam berbuat kebajikan dan taqwa. Dan janganlah tolong-menolong dalam dosa dan permusuhan. ${ }^{27}$

Dalam memahami ayat ini, Imam Ibn Katsir menjelaskan dalam tafsirnya bahwa Allah memerintahkan orang beriman untuk tolong-menolong dalam kebaikan dan meninggalkan kemungkaran. Kebaikan dan meninggalkan kemungkaran adalah taqwa. Allah juga melarang mereka saling tolong-menolong dalam kebatilan, dosa, dan sesuatu yang haram. ${ }^{28}$

Oleh karena itu menurut KH. Ali Mustafa Yaqub, kehadiran seorang Muslim dalam perayaan keagamaan non- Muslim, keikutsertaannya dalam panitia pelaksana perayaan, menyampaikan selamat kepada mereka, mengirimkan kartu selamat, dan

\footnotetext{
${ }^{25}$.Prof. KH.Ali Mustafa Yaqub, Kerukunan Umat Perspektif Al-Quran dan Hadis (Jakarta: Penerbit Pustaka Firdaus, 2008), hal 68

${ }^{26}$. Prof. KH.Ali Mustafa Yaqub, Kerukunan Umat Perspektif Al-Quran dan Hadis (Jakarta: Penerbit Pustaka Firdaus, 2008), hal 69

27.Al-Qur'an dan Terjemahan (Semarang: Penerbit Asy-Syifa', 1998), hal 84

28. Prof. KH.Ali Mustafa Yaqub, Toleransi antar umat beragama (Jakarta: Penerbit Pustaka Firdaus, 2008), hal 17
} 
menandatanganinya adalah termasuk katagori tolong-menolong dalam kebatilan, dosa, dan sesuatu yang diharamkan. ${ }^{29}$ Menurut Beliau perbuatan tersebut termasuk perbutan yang diharam dalam bertoleransi, terutama haram dalam pandangan syariat.

\section{2) Merusak Akidah}

Karena latar belakang pemikiriran ini bermula dari MUI mengeluarkan fatwa yang berisi pengharamkan terhadap umat Islam menghadiri perayaan natal bersama. Maka menurut KH. Ali Mustafa Yaqub, segala sesuatu yang terdapat di dalamnya, potensi merusak agama dan akidah merupakan sesuatu yang jelas di haramkan.

Begitu juga pengucapan Selamat Hari Raya Natal termasuk diharamkan. Hal ini karena terdapat di dalamnya penyebaran terhadap symbol-simbol kekufuran dan kebatilan. Oleh karena itu, hal tersebut diharamkan. ${ }^{30}$

\section{3) Mencampuradukan Hak dan Batil}

Mengenai hal ini, KH. Ali Mustafa Yaqub merujuk pada Qs.Al-Baqoroh ayat 42 , yang artinya :

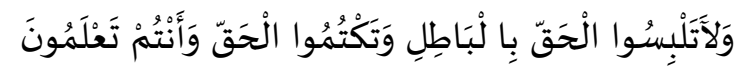

"Dan janganlah kamu campur adukan antara yang hak dengan yang batil dan janganlah kamu sembunyikan yang hak itu, sedangkan kamu mengetahuinya.

Imam al-Thabari menukil penjelasan Imam Mujahid (murid Ibn Abbas) mengenai maksud ayat Dan janganlah kamu campur adukan antara yang hak dengan yang batil adalah menyampuradukkan ajaran Yahudi, Kristen dengan Islam. Hal ini karena agama di sisi Allah hanyalah Islam, sedangkan Yahudi dan Kristen merupakan bid'ah yang tidak berasal dari Allah. ${ }^{32}$

\section{4) Menghadiri Perayaan Agama Non-Muslim (Syahadah al-Zur)}

Berdasarkan firman Allah, dalam QS. al-Furqan ayat 72 :

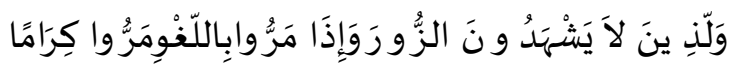

"Dan orang-orang yang tidak memberikan persaksian palsu, dan apabila mereka bertemu dengan (orang-orang) yang mengerjakan perbuatan-perbuatan yang tidak berfaidah, mereka lalui (saja) dengan menjaga kehormatan dirinya. "33

${ }^{29}$.Prof. KH.Ali Mustafa Yaqub, Toleransi antar umat beragama (Jakarta: Penerbit Pustaka Firdaus, 2008), hal 18

${ }^{30}$.Prof. KH.Ali Mustafa Yaqub, Toleransi antar umat beragama (Jakarta: Penerbit Pustaka Firdaus, 2008), hal 21

31. Al-Qur'an dan Terjemahan (Semarang: Penerbit Asy-Syifa', 1998), hal 7

${ }^{32}$ Prof. KH.Ali Mustafa Yaqub, Toleransi antar umat beragama (Jakarta: Penerbit Pustaka Firdaus, 2008), hal 21-22

${ }^{33}$ Al-Qur'an dan Terjemahan (Semarang: Penerbit Asy-Syifa', 1998), hal 292 
KH. Ali Mustafa Yaqub merujuk pada penafsiran sebagian ulama salaf dari kalangan tabi'in, bahwa maksud dari zur disini adalah hari-hari besar non- muslim. Oleh karenanya, sesuai dengan konteks ayat dalam surat al-Furqan tersebut dapat ditegaskan bahwa salah satu tanda penghuni surga adalah tidak menghadiri perayaan hari-hari besar non-Muslim. Hal ini karena menghadiri perayaan tersebut merupakan salah satu tanda penghuni neraka. ${ }^{34}$ Dalam hal ini, jelas bahwa KH.Ali Musatafa Yaqub berperspektif menghadiri perayaan hari-hari besar non-Muslim adalah haram, karena termasuk perbuataan penghuni neraka. Sedangkan sesuatu yang menyebabkan masuk neraka adalah haram.

KH.Ali Mustafa Yaqub menegakan bahwa kehadiran seorang Muslim dalam perayaan keagaamaan non-Muslim serta melakukan semua hal yang telah disebut dalam pembahasan di atas tadi termasuk katagori ajakan kepada kesesatan. Hal ini karena ibadah kepada selain Allah merupakan syirik dan sesat yang diharamkan dalam pandangan syariat. Oleh karena itu, ajakan dan keikutsertaan pada sesuatu yang diharamkan adalah haram. Disamping itu menurut KH. Ali Mustafa Yaqub, kehadiran seorang Muslim dalam perayaan non-Muslim serta semua hal yang disebutkan tadi juga termasuk tindakan aniaya. Tolong-menolong dalam tindakan aniaya merupakan kezaliman. Dalam hal ini, ibadah selain Allah adalah tindakan zalim dan kufur. ${ }^{35}$

Oleh karena itu, Nabi saw bersabda sebagaimana berikut ini:

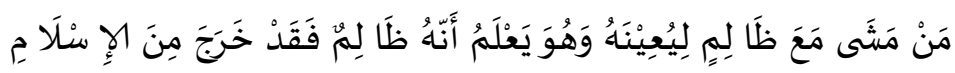

"Siapa yang berjalan bersama orang zalim untuk membantunya, padahal ia mengetahui bahwa orang tersebut zalim, maka ia telah keluar dari Islam",36.

Dengan demikian, keikutsertaan seorang Muslim dalam perayaan keagamaan nonMuslim dengan mengatasnamakan toleransi antar umat beragama, dan semua hal yang berkaitan dengan itu termasuk tolong-menolong dan kerjasama dalam kezaliman. Sedangkan tindakan kezaliman itu adalah haram.

\section{5) Kaidah fiqh}

Di dalam kaidah Fikih disebutkan : الضَرَرُيْزَا لُ "Bahaya mesti dihilangkan”

Di dalam kaidah fikih disebutkan bahwa al-dharar yuzal (bahaya mesti dihilangkan). Sebenarnya kaidah ini ditetapkan oleh ahli Ushul Fikih berdasarkan Hadis

\footnotetext{
${ }^{34}$ Prof. KH.Ali Mustafa Yaqub, Toleransi antar umat beragama (Jakarta: Penerbit Pustaka Firdaus, 2008), hal 21-25

35. Prof. KH.Ali Mustafa Yaqub, Toleransi antar umat beragama (Jakarta: Penerbit Pustaka Firdaus, 2008), hal 26

. Prof. KH.Ali Mustafa Yaqub, Toleransi antar umat beragama (Jakarta: Penerbit Pustaka Firdaus, 2008), hal 27
} 
sebelumnya (la dharar wala dhirar). Adapun makna dari kaidah ini sama dengan apa yang dimaksudkan oleh Hadis tersebut. Kemudaratan dalam segala hal, terutama dalam akidah mesti dihilangkan. Pengambailan kaidah oleh ahli Ushul Fikih dari Hadis tersebut membuktikan penerimaan dan pengamalan mereka terhadap hadis ini. ${ }^{37}$

\section{6) Mengakui kebenaran Agama non- Islam}

Menghadiri perayaan hari-hari besar non-Muslim, mengucapkan selamat hari raya kepada mereka, mengirimkan kartu Natal, dan penandatangan kartu tersebut, ditegaskan oleh KH. Ali Mustafa Yakub ssebagai sikap pengakuan terhadap kebenaran agama nonMuslim. Minimal, terdapat unsur penyebaran dan sosialisasi terhadap symbol-simbol kekufuran dan kesyirikan dalam tindakan tersebut.

Tidak diragukan lagi bahwa tindakan tersebut diharamkan, karena menjerumuskan kepada sesuatu yang diharamkan yaitu pengakuan terhadap kebenaran agama-agama nonMuslim. Dengan demikian, tindakan yang menjerumuskan kepada sesuatu yang diharamkan adalah haram. ${ }^{38}$

Hal-hal di atas merupakan segala sesuatu yang dilarang dalam toleransi antar agama menurut K.H. Ali Mustof Yaqub, dengan argumunetasi batasan-batasan dalam toleransi tidak mencampur adukan antara dimensi sosial dan agama atau akidah. Dan hal tersebut dengan contoh-contohnya telah diungkapkan oleh MUI terkait hal-hal yang merusak agama, termasuk di dalamnya berupa ucapan selamat hari raya kepada agama lain. Hal ini dilakukan sebagai bentuk ikhtiat atau kehati-hatian dalam masalah akidah. Sebagaimana yang diutarakan oleh Prof. Quraish Shihab, larangan yang diberlakukan dalam fatwa MUI itu terhadap orang awam yang tidak mengerti. Orang yang dikhawatirkan akidahnya rusak. Orang yang dikhawatirkan percaya bahwa Natal itu seperti sebagaimana kepercayaan umat kristen. Hal senada di ucapkan oleh menteri agama Dr. Lumkan Hakim Saifudin, M.A, "Jadi yang dilarang itu adalah melakukan ritual keagamaannya, peribadatannya. Tapi kalau ucapan 'Selamat Natal' itu terjadi keragaman dan dengan adanya keragaman ini mudah-mudahan kita bisa saling memahami,"

Lebih lanjut Quraish Shihab menjelaskan dalam pemaparannya terkiat Surat al Mariyam ayat 30-38 "Saya tahu persis ada ulama besar di Suriah memberi fatwa bahwa itu boleh (mengucapkan selamat Natal). Fatwanya itu berada dalam satu buku dan bukunya itu diberikan pengantar oleh ulama besar lainnya, Yusuf al-Qaradawi, yang di Suriah namanya

37. Prof. KH.Ali Mustafa Yaqub, Toleransi antar umat beragama (Jakarta: Penerbit Pustaka Firdaus, 2008), hal 31-32

. Prof. KH.Ali Mustafa Yaqub, Toleransi antar umat beragama (Jakarta: Penerbit Pustaka Firdaus, 2008), hal 32 
Mustafa Al Zarka'a. Ia mengatakan mengucapkan selamat Natal itu bagian dari basa-basi, hubungan baik." ${ }^{39}$. Untuk menjembatani perbedaan pendapat yang ada Quraish Shihab menjelaskan bahwa, kalau Anda mengucapkan selamat Natal, tapi keyakinan Anda bahwa Nabi Isa bukan Tuhan atau bukan anak Tuhan, maka tidak ada salahnya. Ucapkanlah selamat Natal dengan keyakinan seperti ini dan Anda kalau mengucapkannya sebagai muslim. Mengucapkan kepada umat kristiani yang paham, dia yakin bahwa anda tidak percaya. Jadi yang dimaksud itu, seperti yang dimaksud tadi hanya basa-basi. Untuk orangorang yang paham, saya mengucapkan selamat Natal kepada teman-teman saya apakah pendeta. Dia yakin persis bahwa kepercayaan saya tidak seperti itu. Jadi, kita bisa mengucapkan.

Lebih jauh beliau mengiskahkan kontekstual ucapan nabi Ibrahim, nabi Ibrahim dalam perjalanannya menuju suatu daerah menemukan atau mengetahui bahwa penguasa daerah itu mengambil perempuan yang cantik dengan syarat istri orang. Nah, dia punya penyakit jiwa. Dia ndak mau yang bukan istri orang Nabi Ibrahim ditahan sama istrinya Sarah. Ditanya, ini siapa? Nabi Ibrahim menjawab, ini saudaraku. Nabi Ibrahim tidak bohong. Maksudnya saudaraku seagama. Itu jalan. Jadi kita bisa saja. Kalau yang kita ucapkan kepadanya selamat Natal itu memahami Natal sesuai kepercatannya, saya mengucapkannya sesuai kepercayaan saya sehingga tidak bisa bertemu, tidak perlu bertengkar. Jadi syaratnya boleh mengucapkannya asal akidah anda tidak ternodai. Itu dalam rangka basa-basi saja, seperti apa yang dikatakan ulama besar suriah itu.

\section{d. Penerapan Teori Jizyah dan Dzimmah}

Dalam bertoleransi antar umat beragama untuk menciptakan kerukunan antar umat beragama , Menurut KH. Ali Mustafa Yaqub, Al-Quran menurunkan sebuah teori yang disebut dengan teori jizyah dan dzimmah. Falsafah moral dari teori jizyah dan dzimmah ini adalah diakuinya eksistensi agama-agama dan terciptanya kerukunan hidup antar umat beragama, dimana kelompok yang kuat melindungi kelompok yang lemah dan kelompok mayoritas melindungi kelompok minoritas. Mengakui eksistensi agama suatu agama bukanlah berarti mengakui kebenaran ajaran agama tersebut. Dengan teori ini al-Quran ingin menegaskan bahwa kedangan Islam bukan untuk menghanbisi atau memusnahkan agama lain, tetapi agar para pemeluk agama atau umat beragama dapat hidup berdampingan secara damai serta mampu bertoleransi antar umat beragama. ${ }^{40}$

\footnotetext{
${ }^{39}$ Selengkapnya dapat dilihat dihttps://www.youtube.com/watch?v=nOrm3ZFmCs4\&feature=youtu.be

${ }^{40}$. Prof. KH.Ali Mustafa Yaqub, Kerukunan Umat Perspektif Al-Quran dan Hadis (Jakarta: Penerbit Pustaka Firdaus, 2008), hal 44- 46
} 
Oleh sebab itu berdasarkan perspektif al-Quran dan hadis, tidak ada alasan sama sekali bagi kelompok minoritas non-Muslim untuk takut tinggal dan hidup berdampingan di lingkungan mayoritas Muslim. Bila tidak demikian, maka teori jizyah dan dzimmah yang diturunkan oleh Allah melalui Al-Quran dan diterapkan oleh Rosulullah Saw, tidak memiliki arti apa-apa sama sekali.

\section{Penutup}

Setelah megkaji pemikiran KH. Ali Mustafa pendapat KH Ali Mustafa Yaqub mengenai toleransi antar umat beragama, kesimpulan yang didapat sebagai berikut:

1. Menurut KH. Ali Mustafa Yaqub, toleransi merupakan sebuah kewajiban. Beliau merujuk pada QS. al-Mumtahannah ayat 8-9, dimana berdasarkan ayat tersebut dapat disimpulkan bahwa sikap toleransi, harmonis dan kerjasama antara umat islam dan non- Muslim (umat beragama) hanyalah dalam masalah kedunian yang tidak berhubungan dengan permasalahan akidah dan ibadah.

2. KH. Ali Mustafa Yaqub memaparkan batasan bertoleransi dalam Islam, dimana menurut beliau, memang diharuskan adanya garis pemisah (batasan) dalam bertoleransi, beliau merujuk pada QS. al- Kafirun ayat 6. Surah tersebut menurut KH. Ali Mustafa Yaqub, merupakan pemisah yang tegas antara umat beragama dalam bertoleransi pada aspek akidah dan ibadah.

3. Hal-hal yang diharamkan dalam bertoleransi, bahkan beliau jelaskan dengan rinci dengan berdasarkan Al-Qur'an, sunnah, kaidah fikih, dan rasional, bahwasannya menurut beliau ada 8 hal yang diharamkan dalam bertoleransi yaitu tolong menolong dalam dosa, merusak akidah, mencampuradukan hak dan batil , Menghadiri perayaan Agama non- Muslim dengan menyakini kebenaranya, membantu kezaliman, berbuat bahaya, kaidah fiqh, dan mengakui kebenaran agama non- Islam secara itiqadiyan.

4. KH. Ali Mustafa Yaqub juga memberikan solusi dalam menjawab perrmasalahan umat beragama Indonesia saat ini, yaitu timbulnya krisis sikap toleransi. Beliau menjawabnya dengan penerapan teori jizyah dan Dzimmah yang beliau angkat teori tersebut dari Al-Qur'an. Dengan tujuan teori tersebut mampu menciptakan kerukunan hidup antar umat beragama.

5. Bersikap toleran merupakan solusi terciptanya kerukunan di tengah perbedaan agar tidak terjadi perpecahan dalam mengamalkan agama. 


\section{F. Daftar Pustaka}

Ali Mustafa Yaqub, Kerukunan Umat Perspektif Al-Quran dan Hadis, Jakarta: Penerbit Pustaka Firdaus, 2008.

Ali Mustafa Yaqub, Toleransi antar umat beragama, Jakarta: Penerbit Pustaka Firdaus, 2008.

Abdullah Masykuri, Pluralisme Agama dan Kerukunan dalam Keragaman, Jakarta: Penerbit Buku Kompas. 2001

Riki Efendi, Pemikiran dan Aktivitas Dakwah KH Ali Mustafa Yaqub, Skripsi: UIN Syarif Hidayatullah. 2009

Syamsul Hadi, Kerukunan Umat Beragama, Tesis: Universitas Muhammadiyah Surakarta. 2005

Umar Hasyim, Toleransi dan Kemerdekaan Beragama dalam Islam Sebagai Dasar menuju Dialog dan Kerukunan Antar Umat Beragama, Surabaya: Bina Ilmu. 1979

Abdul Kadir, 1992 , dalam lib.ugm.ac.id/jurnal/download.php?dataId=6666

Poerwadarminto. W. J. S. Kamus Umum Bahasa Indonesia, Jakarta: Balai Pustaka. 1986

Yaqub. Ali Mustafa. Toleransi antar umat beragama, Jakarta: Penerbit Pustaka Firdaus. 2008 